\title{
Occurrence of caffeine in wastewater and sewage and applied techniques for analysis: a review
}

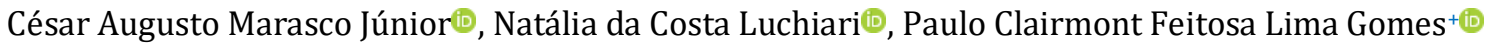

1 São Paulo State University (Unesp), Institute of Chemistry, 55 Prof. Francisco Degni St, Araraquara, São Paulo, Brazil

+Corresponding author: Paulo Clairmont Feitosa Lima Gomes, Phone: +55 163301-9613 email address: paulo.clairmont@unesp.br

\section{ARTICLE INFO}

Article history:

Received: December 21, 2018

Accepted: September 16, 2019

Published: October 1, 2019
Keywords:

1. emerging contaminants

2. caffeine

3. wastewaters
ABSTRACT: Emerging contaminants are substances found in the environment whose concentrations vary from $\mu \mathrm{g}$ to $\mathrm{n} \mathrm{L}^{-1}$ and whose presence in wastewater has gained popularity in the scientific community due to the potential impacts these compounds can cause to the environment. This designation concerns the lack of legislation to regulate their discharge or even to monitor these compounds. Moreover, emerging contaminants are capable of causing harmful effects to nontarget organisms and therefore affect the ecosystem balance. There are several compounds classified as emerging contaminants such as pharmaceuticals, illicit drugs, hormones, pesticides, among others. And among them, caffeine is considered an emerging contaminant and can be highlighted due its presence in medicines, beverages, foodstuff and several other products. In addition, it is a compound used worldwide recognized as a marker of anthropogenic activity. In this review, we present a discussion about emerging contaminants, focusing on caffeine, regulatory aspects that involve the theme, as well as effects on organisms, removal technologies and techniques for analyzing these compounds in environmental matrices.

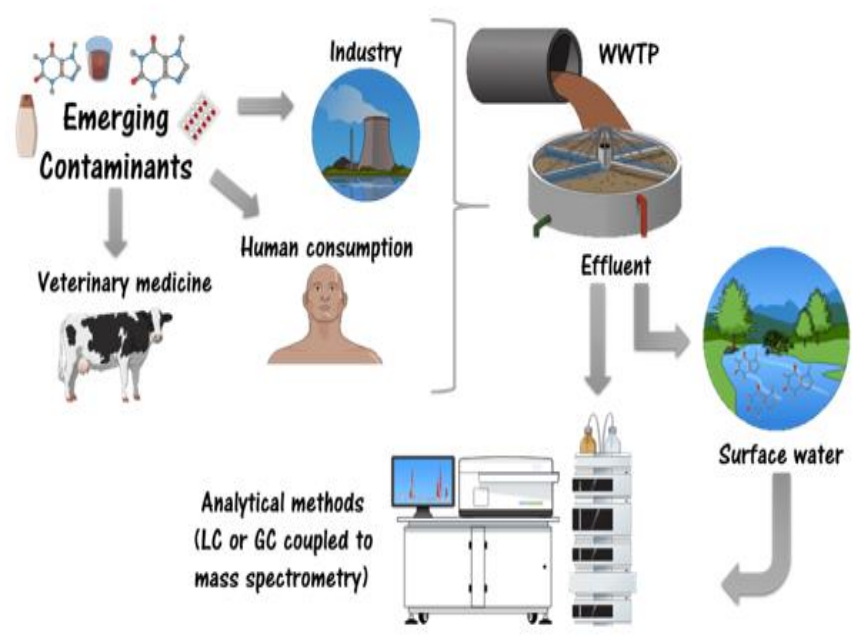

Emerging contaminants in wastewater represent a potential risk to the environment. This review shows what are the emerging contaminants, mainly caffeine, and the other aspects that surround the theme.

\section{CONTENTS}

\section{Emerging Contaminants}

2. Legislation of the emerging contaminants 3. Caffeine as an emerging contaminant: concentrations and ecotoxicological effects 4. Emerging contaminants: removal technologies

5. Emerging contaminants: sample preparation and applied techniques for analysis
6. Conclusion
7. Acknowledgements
8. References

\section{Emerging Contaminants}

Emerging contaminants are chemicals that present a potential risk to human health or to the environment without any standard or legislation established related to the control of these compounds. These compounds are found in the environment at concentrations ranging from $\mu \mathrm{g} \mathrm{L}$ to $n g \mathrm{~L}^{-1}$ in effluents from wastewater treatment plants (WWTPs), untreated sewage, often directly discharged into water bodies, and even in surface and groundwater, respectively ${ }^{1}$. Pharmaceuticals and personal care products (PPCPs), plasticizers, 
illicit drugs, pesticides, hormones and other compounds can be classified as emerging contaminants and the entry routes of these contaminants into the environment are diverse, coming from numerous sources, as it can be seen in Figure 1.

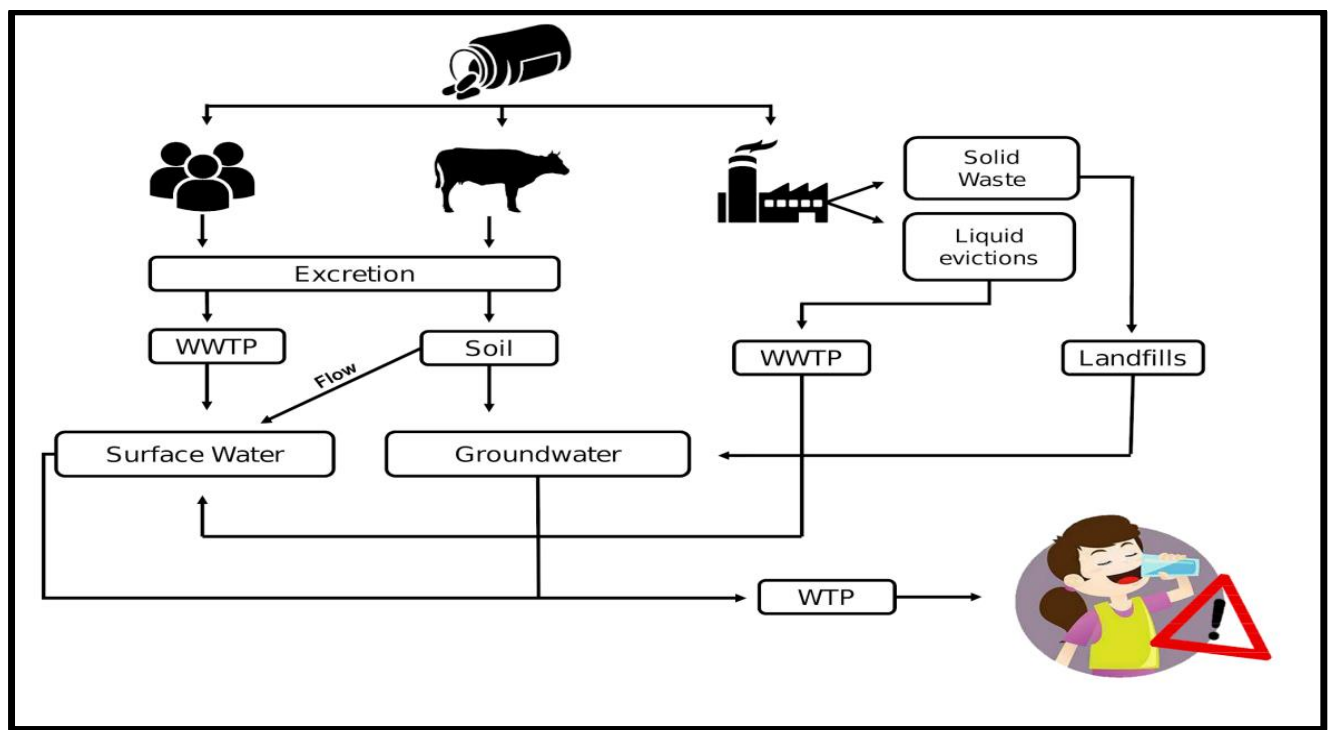

Legend: $\mathrm{WWTP}=$ wastewater treatment plant; $\mathrm{WTP}=$ water treatment plant.

Fig 1. Adapted flowchart of entry routes of PPCPs into the environment ${ }^{1}$.

Currently, these compounds are daily present in modern society, and their potential harmful effects to humans and to the environment have generated attention and alertness, in a way, NORMAN network has already been identified at least 700 substances in the European aquatic environment ${ }^{2}$. Even at these concentration levels, these compounds could cause undesirable effects and risks to human health, fauna and environmental flora $^{3-6}$.

After consumption, pharmaceutical compounds are metabolized, and a significant part is excreted by humans in domestic sewage or even disposed directly into the sewage network after reaching expiration date. We would like to highlight that the pharmaceuticals, when excreted by humans, reach the sewage network in unchanged form or by metabolites, since the pharmaceuticals are not fully metabolized. For example, caffeine (CAF), after consumption, it is rapidly absorbed into the gastrointestinal system, but approximately $5 \%$ is not metabolized, being excreted in the urine, thus reaching the sewage system along with discarded products from food and beverages which contain CAF in their composition ${ }^{7}$.

The same process occurs to pharmaceutical compounds used in veterinary treatment, either for prophylactic purposes or as growth promoters. Furthermore, during the production process by the pharmaceutical industry, residues of pharmaceutical compounds may be discharged directly in water resources after being used to wash industrial parts and having contaminated this resource. This impact could be harmful if there is no adequate treatment prior to disposal into the sewage system ${ }^{8}$.

The US Environmental Protection Agency (US EPA) defines risk as the possibility of a physical, chemical or biological agent in inducing adverse effects on human health or biological systems ${ }^{9}$. Linked to this information, the presence of contaminants in the environment can be considered a risk to fauna and flora, being able to cause irreversible damages to the organisms exposed to these substances.

However, the concern about these contaminants is limited to the impact these can have on water quality and ecosystem balance, but not only affected humans also the fauna and flora exposed to water containing these substances should gain relevance in the proposed discussion. Moreover, aquatic fauna and flora are non-targeted organisms and spend all or most of the lifecycle in this environment.

Inserted in the problematic of the emerging contaminants in the water bodies and the human exposure to these substances, in 2017, the United Nations (UN) and the United Nations Children's 
Fund (UNICEF) presented a report related to the progress in drinking water, sanitation and hygiene stating that about 2.1 billion people do not have access to drinking water and 2.3 billion do not have basic sanitation ${ }^{10}$.

In Brazil, according to the National Water Agency (ANA), 9.1 thousand tons of sewage are generated per day, resulting in a current scenario in which $43 \%$ of the country's population has sewage collected and treated, $12 \%$ use a septic tank, $18 \%$ have their sewage collected and untreated and $27 \%$ have neither collection or treatment ${ }^{11}$.

Still, according to the $23^{\text {rd }}$ Diagnosis of Water and Sewage Services (2017) published by the National Sanitation Information System (SNIS), about $60 \%$ of the urban population has a sewage network, and only $46 \%$ of the total sewage generated is treated ${ }^{12}$. Table 1 shows the sewage collection and treatment data of each Brazilian macro region according to the SNIS.

Table 1. Sewage collection and treatment data in Brazil.

\begin{tabular}{|c|c|c|}
\hline Region & $\begin{array}{c}\text { Sewage } \\
\text { collection }(\boldsymbol{\%})\end{array}$ & $\begin{array}{c}\text { Sewage } \\
\text { treatment }(\boldsymbol{\%})\end{array}$ \\
\hline North & 13.0 & 22.6 \\
\hline Northeast & 34.8 & 34.7 \\
\hline South & 50.6 & 44.9 \\
\hline Southeast & 83.2 & 50.4 \\
\hline Midwest & 59.5 & 52.0 \\
\hline
\end{tabular}

Source: Adapted from National Sanitation Information System $^{12}$.

These figures reveal the lack of effective public policies for the collection and treatment of sewage, demonstrating the precarious service of the population in the service of basic sanitation. In this way, much of the untreated sewage is dumped directly into the environment, causing environmental and sanitary problems.

\section{Legislation of the emerging contaminants}

The authors Sauvé and Desrosiers mentioned Rachel Carson's Silent Spring book as a mark in the history of environmental management and sustainability, and also as the first alert to the emerging contaminants issue ${ }^{13}$.

As previously mentioned, these contaminants do not have specific control legislation and the risk assessment of these pollutants should not be restricted only to their impact on ecosystems, but also to the health of the population, either directly or indirectly, that is constantly in contact with the water containing these pollutants ${ }^{2,14}$.

The discussion becomes even more relevant, supported by the United Nations World Report on Water Resources Development, which calls for research to understand the emerging contaminants dynamics and to improve technologies to remove these compounds from sewage and wastewater ${ }^{15}$.

To accomplish this goal, based on research to study these pollutants, several countries have implemented legal regulations for some substances, which have been prioritized according to the adverse effects they cause in organisms such as fish from Danio rerio species and mollusk Mytilus galloprovincialis among others ${ }^{16}$.

The United States and the European Union have demonstrated some concern about this issue by creating directives to regulate or control the disposal of these substances.

The Environmental Protection Agency (EPA) is the US agency responsible for the legal regulation of the substance's disposal into the environment, through two federal laws: the Clean Water Act (CWA) and the Safe Drinking Water Act $(\text { SDWA })^{17}$.

One of the first steps by US agencies to attempt to establish limits and regulations on PPCPs came under the Food Quality Protection Act (FQPA) and amendments to the SDWA. These amendments authorized the US EPA to track chemicals and formulations that could show some type of endocrine activity if they reached any water supply line ${ }^{14}$.

EPA uses two main regulations to monitor emerging contaminants in water: The Contaminant Candidate List (CCL) and the Unregulated Pollutant Monitoring Rule (UCMR).

The CCL lists water contaminants that are not subject to any regulations, setting priorities to assess the occurrence and toxicity of these contaminants. The SDWA regulates that the EPA must publish the CCL every five years and regulate at least five contaminants, demonstrating the potential adverse effects a contaminant can exert on human health and the environment ${ }^{17}$.

EPA made available in 2016 the Contaminant Candidate List-4 (CCL-4), the fourth update presents contaminants candidates for future regulations. It includes, among the hundred chemical compounds such as estrogens, pharmaceutical compounds, personal care and 
hygiene products, industrial products and pesticides ${ }^{16,18}$. Moreover, the fifth update of this list (CCL-5) is already under development.

The second mechanism is the UCMR, developed in coordination with the CCL. EPA collects data about contaminants suspected of being present in drinking water and that do not have limits defined by SDWA. The results are compared with ecotoxicological research and risk assessment to determine if a contaminant should have an established threshold and thus be inserted into the $\mathrm{CCL}^{17}$.

In the same way, the European Environment Agency (EEA) assists member countries of the European Union (EU) in making relevant decisions for environmental improvement and the impact of the adopted policies ${ }^{19}$. The EEA works under the European Water Framework Directive (EU WFD) with the aim of ensuring quality for all EU waters. Given the large number of chemicals released into the environment, Von der Ohe et al. have presented a new approach for assessing the ecotoxicological risk used to prioritize 500 organic contaminants ${ }^{20}$.

In the European Union, actions to raise the priority compounds to be legislated began in $1999^{16}$. By taking the European Union's regulations as an example, the REACH (registration, evaluation, authorization and restriction of chemicals) regulates the use of almost all chemicals into the European Union (EC Regulation No. $1907 / 2006)^{2}$. To facilitate this study, in 2005, the European Commission funded the NORMAN project to promote a permanent network of reference laboratories and research centers to support EU member countries concerning the environmental impacts caused by the adoption of their economic policies ${ }^{21}$.

The creation of laws and regulations presents itself as a viable way to aid in the control of these contaminants. Currently, most of these compounds are not regulated in many parts of the world, including in Brazil, but as discussed earlier there are some attempts in the European Union and the US to try to reduce environmental contamination by these substances. It is therefore believed that effective regulations are the basis for efficient water resource management.

\section{Caffeine as an emerging contaminant: concentrations and ecotoxicological effects}

Caffeine or 1,3,7-trimethylxanthine, with molecular formula corresponding to $\mathrm{C}_{8} \mathrm{H}_{10} \mathrm{~N}_{4} \mathrm{O}_{2}$, as it can be seen in Figure 2, is an alkaloid from the xanthine group naturally found in the environment.

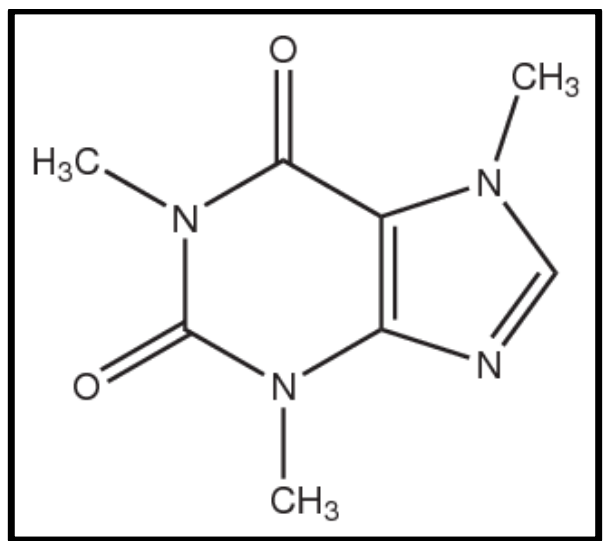

Fig 2. Planar structure of caffeine.

Caffeine is present in tea, chocolate, sodas and in a wide variety of food consumed worldwide, culminating in its occurrence in wastewater and eventually causing aquatic ecosystems impairment ${ }^{22,23}$. Moreover, it can be considered as a marker of anthropogenic activity, since its consumption is thoroughly related to human habits ${ }^{16,23,24}$, and it is also persistent in environmental matrices, standing out as one of the most ubiquitous wastewater microcontaminants ${ }^{25}$.

In order to evaluate the water quality and to observe possible contamination by effluents produced by the anthropogenic action, it is important to determine the presence of such contamination markers.

The ideal marker should assertively indicate the contamination source, and moreover, establish a quantitative relationship with the contamination by other chemical compounds. According to Gonçalves, Rodrigues and Silva-Filho (2016), the average global consumption per day of caffeine is approximately $70.0 \mathrm{mg}$ per person ${ }^{24}$. However, countries like Switzerland, United Kingdom and the United States of America have this average consumption per person estimated at $300 \mathrm{mg}, 440$ $\mathrm{mg}$ and $210 \mathrm{mg}$, respectively ${ }^{25}$.

Caffeine presents stability, high solubility and low partition coefficient octanol-water $\left(\mathrm{K}_{\mathrm{ow}}\right)$. These characteristics permits caffeine detection in the environment which are essential to correlate the risk it may offer to humans and ecosystems ${ }^{16,22,26,27}$. Recent studies confirm the presence of this substance in environmental matrices.

Edwards, Kulikov and Garner-O’Neale (2015) analyzed wastewater from two WWTPs in Barbados, a city with about 300 thousand people, 
and the concentrations of caffeine determined ranged from $0.100-6.90 \mu \mathrm{g} \mathrm{L}^{-125}$. Senta et al. (2015) determined caffeine at concentrations of 17.6-67.6 $\mu \mathrm{g} \mathrm{L}^{-1}$ in $13 \mathrm{WWTPs}$ located in northern, central and southern Italy ${ }^{28}$. These WWTPs are responsible for the collection and treatment of sewage of about 50 to 500 thousand inhabitants, according to the region in which each one is located.

Even in one of the most remote regions of the planet, Antarctic Peninsula, González-Alonso et al. (2017) determined caffeine in the concentration of $71.3 \mathrm{ng} \mathrm{L}^{-1}$ during the period from December 2012 to February 2013 in ten sites that were thought to have anthropogenic impact, whether due to tourism or proximity to human settlements ${ }^{29}$.

Williams et al. (2019) determined caffeine at concentrations up to $37.5 \mu \mathrm{g} \mathrm{L} \mathrm{L}^{-1}$ when analyzing surface water of the Ahar River, which flows through the city of Udaipur, India, a city with about 450 thousand people, which has no wastewater treatment ${ }^{30}$.

In Brazil, Ferreira (2005) detected caffeine in the concentration of 134 to $147 \mathrm{ng} \mathrm{L}^{-1}$ in the Guanabara Bay, Rio de Janeiro (RJ), Brazil, while in the Leopoldina Basin the concentration of caffeine in the water samples collected from the rivers reached concentrations of 160 to $357 \mu \mathrm{g}$ $\mathrm{L}^{-1} 27$. The sample area of the study is highly populated, with an estimated population of $1,135,000$ inhabitants, distributed among 30 housing projects and 8 slums, accounting for the largest portion of untreated domestic and industrial sewage discharged in the Guanabara Bay.

Sposito et al. (2018) detected caffeine in all analyzed samples of the Dourados and Brilhante rivers $^{31}$. The highest concentration of caffeine determined was $1040 \mathrm{ng} \mathrm{L}^{-1}$, measured at a point near the city of Dourados, a city with 218,000 inhabitants.

Gonçalves, Rodrigues and Silva-Filho (2016) analyzing water from the Paquequer River determined caffeine from $0.150-47.5 \mu \mathrm{g} \mathrm{L}^{-124}$. The Paquequer River flows through the urban area of the city of Teresópolis, with a population of approximately 125,000 inhabitants. The city of Teresópolis has no wastewater treatment plant and therefore Paquequer is the main body of water that receives most of the urban drainage and sanitary effluents drained without any treatment.

In the study of Campanha et al. (2018), to investigate the occurrence and spatiotemporal distribution of some important pharmaceuticals, hormones, and triclosan in surface water of the Monjolinho River determined caffeine at concentration of $129,585 \mathrm{ng} \mathrm{L}^{-132}$. The Monjolinho River is located in São Carlos city, central region of São Paulo state. This city houses about 220,000 inhabitants and has an extensive industrial park, especially in the sectors of automotive, refrigeration, paper and cardboard, school supplies, cosmetics, and textiles.

Montagner and Jardim (2011) determined caffeine in the Atibaia River and the levels varied between 174 and $127 \mathrm{ng} \mathrm{L}^{-133}$. The Atibaia River basin, located in São Paulo state (Brazil), covers an area of approximately $2,800 \mathrm{~km}^{2}$ and is the main source of public supply in the city of Campinas, in São Paulo state, Brazil.

All these studies show that caffeine besides to be an anthropogenic marker, is an emerging contaminant and thus assessing exposure to a given risk is important to ensure the integrity of human health and the diversity of aquatic ecosystems ${ }^{34-36}$.

Aguirre-Martínez, Delvalls and Martín-Diaz (2015) have studied the markers effects such as caffeine at concentrations of $0.1,5.0,15,50 \mu \mathrm{g} \mathrm{L}^{-1}$ and carbamazepine at concentration levels of 0.1 , $1.0,10,50 \mu \mathrm{g} \mathrm{L}^{-1}$ in mussels of the species Corbicula flumine ${ }^{37}$. After 21 days of experiment, it was observed breaks in the DNA chain in the digestive gland tissues.

Cruz et al. (2016) demonstrated that long-term exposure to caffeine concentrations at $\mu \mathrm{g} \mathrm{L}^{-1}$ level induced oxidative stress in mollusks of Ruditapes philippinarum $^{38}$.

Pires et al. (2016) studied the caffeine effects on annelids from species Arenicola marina and Diopatra neapolitana ${ }^{39}$. After 28 days of exposure, oxidative stress was induced in both species. $D$. neapolitana presented a $12.5 \%$ mortality rate at concentrations of 3.00 and $18.0 \mu \mathrm{g} \mathrm{L}^{-1}$. A. marina mortality rate was recorded only at the highest concentration $\left(18.0 \mu \mathrm{g} \mathrm{L}^{-1}\right)$, where $22.2 \%$ of the individuals did not survive.

According to the mentioned characteristics and the intense consumption of pharmaceutical drugs and food containing caffeine, these habits affect several water compartments, such as surface or groundwater, or even sediments and soils.

Based on these previous published studies is clear the concern to monitor caffeine in wastewater, although, other emerging contaminants could be found increasing the risks of harmful effects. Also associated with this concern the current wastewater treatment plants are 
designed only to reduce the load of organic compounds such as, nitrogen, phosphorus and sulfur compounds, odor control, wastewater turbidity and reduce microbial pathogens.

In order to achieve WWTP aims different treatment technologies using bioreactors such as up-flow anaerobic sludge blanket (UASB) reactors, aeration ponds, aerated lagoons, activated sludge and membrane bioreactors. All these technologies were not designed for the removal of emerging contaminants ${ }^{16,40}$. Due to the growing need to reuse water improvements in sewage collection and treatment systems are essential.

\section{Emerging contaminants: removal technologies}

The conventional sewage treatments were designed to remove or to decrease the pathogens and the charge of organic/inorganic pollutants to avoid the eutrophication of lakes and rivers which the wastewater is dispensed. In general, WWTPs have been not designed to remove residues of organic compounds such as pharmaceuticals compounds which are frequently detected in effluents and influents from wastewater treatment plants $^{41}$.

According to the pharmacodynamics and pharmacokinetics, pharmaceutical compounds could be discharged in the environment as a metabolite, unchanged or conjugated form. In the WWTP these compounds are either partially retained in the sludge or metabolized. Their removal in WWTPs is variable and depends the substance properties and process conditions (e.g. sludge retention time, hydraulic retention time, temperature and organic loading).

Activated sludge is the most used process present in sewage treatment plants, according to Buttiglieri and Knepper $\left(2008\right.$, p. 3) ${ }^{41}$ "is the biomass produced in wastewater by the growth of organisms in aeration tanks in the presence of dissolved oxygen responsible for removal of organic and inorganic compounds". In Brazil, associated to activated sludge there may be other sewage treatment technologies such as: stabilization ponds or anaerobic sludge blanket bioreactors.

Many technologies have been studied and developed involving the emerging contaminants removal such as membrane bioreactor, ozonation, photocatalytic processes and anaerobic bioreactors.
In the paragraphs below, we present a brief discussion about each one of these technologies.

The membrane bioreactor technology (MBR) combines biological-activated sludge process and membrane filtration. This technology has emerged due to the increasing need for water reuse and together with a better understanding of the emerging contaminants dynamics in the wastewater. The MBR demonstrate suitable to become a technology capable to remove these contaminants. The most widely applied membrane separation processes are microfiltration (MF), ultrafiltration (UF), nanofiltration (NF), reverse osmosis (RO), electrodialysis (ED) and electro deionization $(\mathrm{EDI})^{42}$.

The two main processes that use MBR technology are reverse osmosis and nanofiltration. Both mechanisms remove efficiently various substances, being a technology of choice for emerging contaminants removal in developed countries ${ }^{43}$.

Anaerobic bioreactors are units containing a diverse microbiota which promotes different types of chemical and biochemical reactions applied in the wastewater treatment. These units are used in the Southeast of Brazil since it requires climate with average of temperature of $20{ }^{\circ} \mathrm{C}$ to avoid low microbial activity. The anaerobic reactors present advantages: demand low land area, present low energy consumption compared to aerobic processes, microbiota requires low nutrition substrate, low production of solids compared to aerobic processes, produces methane and hydrogen which could be used as power source and present tolerance to wastewater containing high organic load. Although, the anaerobic bioreactors present as disadvantages: possible generation of bad odors such as $\mathrm{H}_{2} \mathrm{~S}$, not suitable to remove nitrogen, phosphorus and pathogen, requires post-treatment, the anaerobic microbiota present a complex biochemistry and it is susceptible to inhibition, bioreactor to reach steady-state regimen can be slow. The removal process involving anaerobic bioreactors are mainly adsorption in the biomass and chemical and biochemical reactions with the microbial community present in the biomass ${ }^{44}$.

The UASB bioreactor expanded the application of anaerobic bioreactors in the sewage treatment system present in many different Brazilian cities. There are many other anaerobic bioreactors configurations applied to remove emerging contaminants. For example, horizontal fixed-bed anaerobic bioreactor (HAIB) is a versatile and 
simple to be maintained. HAIB is a fixed-bed bioreactor containing biomass immobilized in polyurethane foams. The polyurethane foams permit the biomass growth and attachment. The wastewater flow through as tubular ideal reactor. In the different sections along the bioreactor length, the anaerobic microbial community is diverse favoring different types of metabolism, therefore, the removal of organic compounds and wastewater with high organic load ${ }^{45,46}$.

The HAIB bioreactor was successfully applied for removal of benzene, toluene, ethyl benzene and ethanol $^{47}$, pentachlorophenol ${ }^{48}$, bioremediation of gasoline-contaminated groundwater ${ }^{46}$, linear alkylbenzene sulfonate ${ }^{49}$, sulfamethoxazole and ciprofloxacin $^{50}$, sulfamethazine ${ }^{51,52}$, sulfamethoxazole and trimethoprim ${ }^{53}$.

Ozone has a strong oxidative action allowing to be used in the treatment of surface water, groundwater or wastewater. Ozone-based technologies have the common objective to improve the disinfection and removal of organic compounds in the water. The search for this optimization is not only due to the fact that it is an expensive oxidant, but also because ozone induces the formation of toxic intermediate radicals. In addition, coupling ozonation with other processes, such as coagulation and filtration or even with the aid of UV, improves the biodegradability and organic compounds removal ${ }^{54}$.

The advanced oxidative processes (AOPs) have high mineralization capacity of organic matter. However, the large-scale applications for these oxidative processes are still scarce and future applications are aimed with the use of solar energy and photocatalysis. Therefore, two AOPs have concentrated most of the studies which are the homogeneous catalysis by the photo-Fenton reaction and the heterogeneous catalysis assisted by $\mathrm{UV} / \mathrm{TiO}_{2}{ }^{55}$.

Although there are many technologies for wastewater treatment, some mentioned in this article, adsorption has still been widely used and studied, albeit limited by the appearance of new materials.

The most common sorbent materials used are activated carbon, zeolites, silica gel and activated alumina. However, advances in nanoscale technology have led to the development of new nanomaterials, mainly the carbon-based materials which are already applied in water treatment processes and carbon-based material obtained from solids residues (biochar) are environmentally friendly ${ }^{56}$.

The development of new technologies and materials for wastewater treatment and water supply have grown significantly. However, there is a need for advancement in wastewater treatment technologies designed for emerging contaminants removal. As there is no single treatment capable to remove all compounds, moreover, there are different types of emerging contaminants, with distinct physicochemical properties which would require different treatments technologies.

Therefore, treatment technology suitable to be applied should be chosen according to the characteristics of the effluent (organic load, turbidity, conductivity, chemical and biochemical oxygen demand, emerging contaminants present). To evaluate the removal efficiency from a treatment technology is fundamental to apply analytical tests whether a target compounds or target class of compounds are evaluated in order to estimate the treatment efficiency.

The development of new treatment technologies is mainly focus in the removal efficiency besides the transformation products formed during the treatment applied. There is a lack of studies in this area requiring toxicity research involving the compounds formed during the wastewater treatment.

\section{Emerging contaminants: sample preparation and applied techniques for analysis}

According to the arguments presented above, and, because there is no specific legislation that regulates the disposal of these contaminants in the environment, the scientific community raised the concern about the development of analytical methods able to determine emerging contaminants present in several environmental matrices.

Moreover, during 2000-2010 occurred a huge development in analytical instrumentation, specially, in equipment using mass spectrometry. The development of new configuration improving the sample ionization, new mass analyzer such as Orbitrap or combining mass analyzers such as quadrupole $(\mathrm{Q})$ with linear ion-trap (QTRAP) and $\mathrm{Q}$ with time-of-flight (QToF) permitted to detect compounds in pg L $\mathrm{L}^{-1}$ to $\mu \mathrm{g} \mathrm{L}^{-1}$ concentration. This analytical advancement was essential to found emerging contaminants in wastewater and sewage.

Currently, most of the literature published on the issue of emerging contaminants is focused on 
the monitoring of target compounds. This traditional approach may prove to be insufficient since it excludes the metabolites or possible transformation products generated which could presents the environmental relevance. And many of these transformation products or metabolites may be "ecotoxicologically" more harmful than the target compound itself. Despite the efforts, it is still difficult to screen untargeted compounds due to a lack of analytical standards and databases that allow the search of a possible structure for a given elemental composition within the instrument software $^{57}$.

Although the occurrence of pharmaceutical compounds in the environment has been reported for more than 20 years, in 2007 official methods have emerged using liquid and gas chromatography coupled to mass spectrometry for the determination of these compounds, respectively ${ }^{58,59}$. Thus, the use of LC-MS/MS for the determination of these substances were systematized, mainly in Europe and the United States of America ${ }^{60}$.

The determination of pharmaceutical compounds in environmental samples can also be performed by gas chromatography coupled to mass spectrometry (GC-MS). However, many compounds are not thermally stable, making GCMS determinations difficult, and derivatization reactions would be essential. Since most pharmaceuticals are soluble in the mobile phase, high performance liquid chromatography coupled to sequential mass spectrometry (LC-MS/MS) has been widely used as a method of analysis.

According to Silva and Collins (2011), this fact can be explained by the versatility of the LCMS/MS technique, which can be used for analytes with different polarities ${ }^{61}$. This method is able to reach limits of detection and quantification at ng L ${ }^{-1}$ concentration level.

Silva et al. (2011) determined simultaneously 43 drugs in surface waters of the Ebro river basin, Spain, of different therapeutic classes, such as anticonvulsants, anti-inflammatories, antidepressants, hormones and others in a concentration range of the order of $n g \mathrm{~L}^{-1}$ by liquid chromatography coupled to a tandem mass spectrometry (LC-MS/MS) ${ }^{62}$. Stewart et al. (2014) carried out a multi-residue analysis of 46 pharmaceutical drugs in estuaries also using LCMS/MS, and it was possible to quantify 21 of the substances classified as emerging contaminants present located in Auckland, New Zealand ${ }^{63}$.
Despite the several advances in analytical instrumentation, the sample preparation step is still necessary and extremely important. Environmental samples are complex, and it is essential to preconcentrate the analytes, eliminate or remove with high efficiency interferents and sample components. This process is essential to decrease the matrix effect and to avoid possible damages to the equipment.

Previous published papers as Silva et al. $(2011)^{62}$ and Williams et al. (2019) ${ }^{30}$ presented solid phase extraction (SPE) as the technique of choice for conducting their experiments and this technique of sample preparation proved to be satisfactory for the determination of emerging contaminants.

Introduced in the early 1970s, the SPE is an extraction technique by sorption. This technique appeared to replace the traditional liquid-liquid extraction (LLE), since the LLE requires large volumes of samples and solvents, there is the formation of emulsion and still the solvents used in this kind of extraction are toxic like chloroform, toluene, hexane and others, and end up generating toxic and non-environmentally friendly waste ${ }^{64,65}$.

SPE is currently the most popular technique of sample preparation and the most common form uses solid phases called sorbents immobilized in a cartridge. The commercially available solid phases are based on organic groups such as C18, C8, cyclohexyl, phenyl and others chemically bonded to silica. These phases are the same used in the columns of liquid chromatography. Besides these, other phases are characterized as polystyrene divinylbenzene, with high surface area, great stability in different $\mathrm{pH}$ ranges and high retention capacity, and the graphitized carbon, responsible for low resistance mechanical materials, homogeneous, crystalline structure and great retention power ${ }^{64}$.

Although there is an extensive variety of commercially available sorbents, the most commonly known and used commercial hydrophilic sorbent is Oasis HLB from Waters. This material is a macroporous $\operatorname{poly}(\mathrm{N}$ vinylpyrrolidone-divinylbenzene) (PVP-DVB) copolymer with a high surface area. This stationary phase proved to be versatile, becoming popular for the sample preparation due to being suitable to extract compounds with different polarities, cleaning of complex matrices with effectiveness in terms of interference removal ${ }^{66}$. This stationary phase was chosen in many studies of emerging 
contaminants in environmental samples for the extraction and determination of pharmaceuticals compounds $^{29,62}$, illicit drugs ${ }^{67,68}$ among other compounds.

The analytical method development using SPE in environmental analysis allowed the use of large sample volumes, around 50 to $1000 \mathrm{~mL}^{66}$, and this way as indicated by Jardim $\left(2010\right.$, p. 15) ${ }^{64}$ "the concentration can be increased by a factor of 100 to 5000 , making possible the qualitative and quantitative analysis at the trace levels."
Other hydrophilic polymeric sorbents have been also developed, such as Bond Elut Plexa (Agilent Technologies) $)^{66}$ or Strata-X (Phenomenex) $)^{66,69}$, which are the most commonly used chemically modified sorbents with polar functionalities. In the Table 2, we show some studies and the results obtained, mainly for the extraction of pharmaceutical compounds in environmental samples, using the stationary phases for SPE discussed in this article.

Table 2. Application of some commercial polymeric sorbents for SPE.

\begin{tabular}{|c|c|c|c|c|c|c|c|}
\hline \multirow{2}{*}{ Sorbent } & Target analytes & Matrix & $\begin{array}{c}\text { Sample } \\
\text { volume }(\mathbf{m L})\end{array}$ & $\begin{array}{c}\text { Recovery } \\
(\boldsymbol{\%})\end{array}$ & $\begin{array}{c}\text { Matrix } \\
\text { effect (\%) }\end{array}$ & $\begin{array}{c}\text { LD } \\
\left(\mathbf{n g} \mathbf{L}^{-1}\right)\end{array}$ & $\begin{array}{c}\text { Reference } \\
\text { Oasis HLB (Waters) }\end{array}$ \\
\cline { 2 - 8 } & Pharmaceuticals & $\begin{array}{c}\text { Surface and } \\
\text { wastewater }\end{array}$ & 50.0 & $21.0-116$ & $6.00-123$ & $1.00-500 *$ & {$[70]$} \\
\cline { 2 - 8 } & Pharmaceuticals & $\begin{array}{c}\text { Surface and } \\
\text { wastewater }\end{array}$ & $100-500$ & $35.0-116$ & $<25.0$ & $0.500-60.0$ & {$[71]$} \\
\cline { 2 - 8 } & Illicit drugs & Surface water & 250 & $71.0-104$ & $80.0-100$ & $0.0100-1.54$ & {$[68]$} \\
\hline Strata-X (Phenomenex) & Pharmaceuticals & Wastewater & 100 & $26.0-117$ & $70.0-130$ & $0.100-5.00$ & {$[72]$} \\
\hline $\begin{array}{c}\text { Bond Elut Plexa (Agilent } \\
\text { Technologies) }\end{array}$ & PCPs & Surface water & 500 & $46.0-101$ & $45.0-108$ & $1.00-4.00$ & {$[73]$} \\
\hline
\end{tabular}

Legend: LD = limit of detection; *method quantification limits.

Source: Withdrawn and adapted from Gilart et al. ${ }^{66}$.

The SPE is a technique that requires at least four steps for the sample preparation: sorbent conditioning, sample loading, clean-up (remove the interferers and matrix concomitants) and elution of the analytes ${ }^{64,69,74}$. Figure 3 shows these steps:

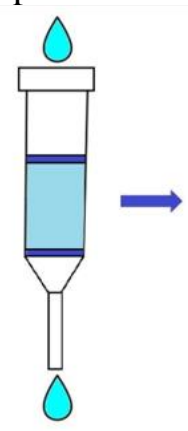

(1)

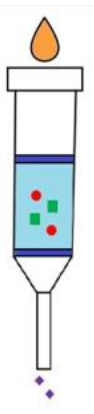

(2)

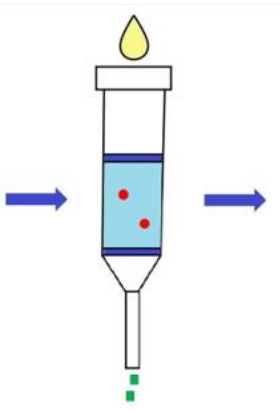

(3)
(4)

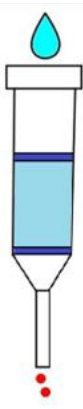

Legend:

Analytes

Interferers

Fig 3. Adapted SPE analytical steps: 1) conditioning; 2) loading sample; 3) wash; 4) elution ${ }^{74}$.
This technique has extensive applications being a consolidated technique in sample preparation, mainly in environmental field. Moreover, EPA method establishes SPE as sample preparation technique of choice for organic contaminants ${ }^{58,74}$.

It is also worth mention the development of new SPE sorbent materials produced several modifications in recent years, with most based on miniaturization and automation resulting in novel extraction techniques, such as solid phase dynamic extraction (SPDE), microextraction by packed sorbent (MEPS), matrix solid phase dispersion (MSPD) stir-bar sorptive extraction (SBSE), solid phase microextraction (SPME) and other technologies also applied in the sample preparation of wastewaters ${ }^{66,74}$. However, in this review, we focus only on traditional SPE (off-line) and on-line.

Although a conventional setup of SPE (SPE offline) is the most common choice and the most used method for the sample preparation it is a tedious and time-consuming procedure. In this mode the chromatography analysis is separated from sample preparation procedure and in order to avoid sample 
cross-contamination, sample loss, decrease in the volume of solvents usage and increase the analytical frequency, it is fundamental to integrate sample preparation and chromatographic separation.

On-line SPE incorporates all the steps involved in conventional SPE into an integrated system for chromatography. In order to effectively occur this integration between sample preparation and chromatography, a strategy called column switching mode enables integrated analysis in an efficient and productive way ${ }^{69,74}$.

\section{A}

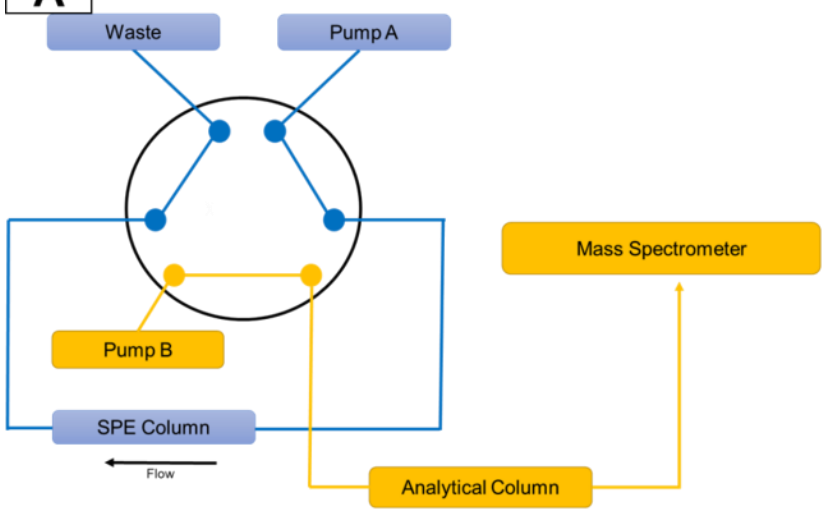

The coupling of this technique has become accessible, based on an instrumental arrangement that includes the coupling of a six-port valve with two positions to the system ${ }^{74,75}$. In this way, the system works using two pumps, in which a pump loads the sample into the sample preconcentration column, where the analytes are retained. The other pump then elutes the analytes using the gradient elution for the analytical column ${ }^{74,75}$. The used system can be seen in the Figure 4.

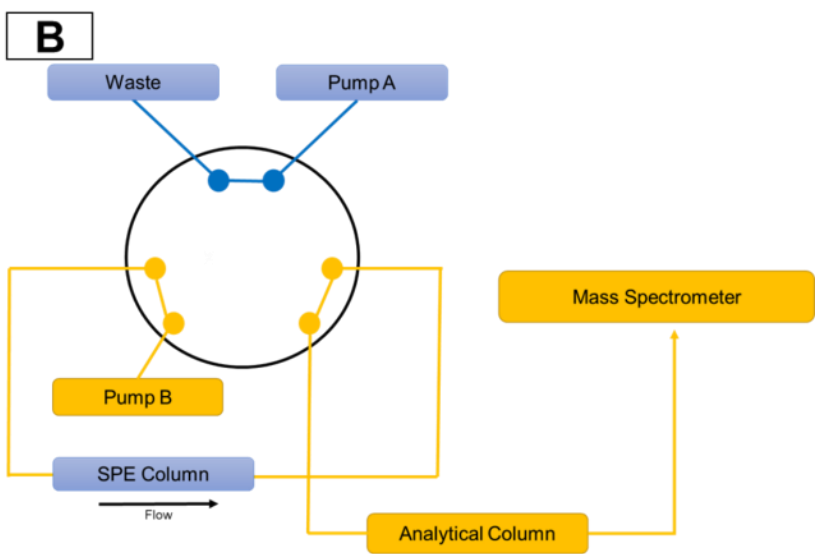

Fig 4. Column switching configuration in backflush mode: a) loading; b) elution.

According to mentioned above and demonstrated by the Figure 4, the on-line mode overcomes some limitations of off-line mode, in addition to avoid problems such as sample crosscontamination, minimizes the volume of waste generated and reduces the amount of solvent used, although it might require available dedicated devices or instrumental arrangement with valves and pumps ${ }^{75}$. Table 3 shows some advantages and disadvantages among SPE on-line and off-line.

Table 3. Comparison between SPE configurations.

\begin{tabular}{|c|c|}
\hline SPE on-line & SPE off-line \\
\hline Requires small sample volumes & High sample volumes are necessary \\
\hline Reusable cartridges & Disposable cartridges \\
\hline $\begin{array}{c}\text { Less flexibility, most systems do not allow coupling } \\
\text { Direct and fast elution of the sample after } \\
\text { preconcentration }\end{array}$ & $\begin{array}{c}\text { Sequential extraction and possibility of using different } \\
\text { combinations of cartridges connected in series }\end{array}$ \\
\hline $\begin{array}{c}\text { Minimal consumption of organic solvents } \\
\text { time) }\end{array}$ \\
\hline $\begin{array}{c}\text { Reduced analysis time and high throughput } \\
\text { Expensive equipment (requires auxiliary instruments } \\
\text { such as pumps and valves assemblies) }\end{array}$ & Consumption of organic solvents for elution \\
\hline Sounger analysis time
\end{tabular}

Source: Withdrawn and adapted from Rodriguez-Mozaz et al. ${ }^{76}$. 
The development of new stationary phases permitted to develop suitable methods in complex environmental matrices and provide an efficient and well-succeed analysis. In addition, the sample preparation procedure automation through column switching and coupling to the detection system (LC-MS/MS) permitted a great progress in analyzing environmental samples, especially emerging contaminants, proving to be fast, accurate and with reduced solvent consume.

\section{Conclusion}

Emerging contaminants have attracted the scientific community attention due to the wide variety of compounds that fit into this class. Those compounds can cause harmful effects to ecosystems balance and even to human health, besides the lack of research related to this topic.

In this review, the focus was given to caffeine, a natural substance present in several consumed products such as medicines, personal care products and food in general. Considered as a marker of anthropogenic activity, caffeine has been the subject of ecotoxicity studies at similar concentrations to those found in the environment and adverse effects on organisms of several species have been reported.

The risks caused by caffeine and emerging contaminants to the biota and the lack of legislation capable of regulating or controlling the disposal of these contaminants into the environment are the main issue.

Moreover, we can notice the efforts on the development of new sorbent materials, as well as on the advancement of analytical instrumentation in order to reach ever lower concentrations. Among the existing sample preparation techniques, SPE is considered the most extensively used technique due to its advantages that include simplicity, flexibility, automation possibilities and many other factors. SPE is a technique that allows enhancement to further increase the quality of analysis with better precision and accuracy.

Allied to this, seeking alternative solutions or technologies for emerging contaminants removal in association to the mass spectrometry and sample preparation advancement are an important role to evaluate the proposed removal technology. The development of these analytical techniques and methods advancement provide essential pieces of information to understand the emerging contaminants dynamics in the environment as well as permit monitoring them in the most diverse environmental matrices supporting ecotoxicological researches related to human, fauna and flora effects.

Therefore, government and environmental authorities' decisions should be based on scientific data which permits to elaborate normative controlling the sewage and wastewater discharge, which would reduce the emerging contaminants present in the wastewater and others environmental matrices.

\section{Acknowledgements}

The authors are grateful to Fundação de Amparo à Pesquisa do Estado de São Paulo (FAPESP No. 2016/03369-3, 2018/11700-7, 2018/22393-8 and INCT-DATREM No. 14/509454), Conselho Nacional de Desenvolvimento Científico e Tecnológico (CNPq), Coordenação de Aperfeiçoamento de Pessoal de Nível Superior (CAPES) and the Institute of Chemistry - São Paulo State University (IQ/UNESP).

\section{References}

[1] Quesada, H. B., Baptista, A. T. A., Cusioli, L. F., Seibert, D., Bezerra, C. O., Bergamasco, R., Surface water pollution by pharmaceuticals and an alternative of removal by low-cost adsorbents: A review, $\begin{array}{llll}\text { Chemosphere } & 222 & \text { (2019) 766-780. }\end{array}$ https://doi.org/10.1016/j.chemosphere.2019.02.009.

[2] Geissen, V., Mol, H., Klumpp, E., Umlauf, G., Nadal, M., Van Der Ploeg, M., Van De Zee, S. E. A. T. M., Ritsema, C. J., Emerging pollutants in the environment: A challenge for water resource management, International Soil and Water Conservation Research 3 (1) (2015) 57-65. https://doi.org/10.1016/j.iswcr.2015.03.002.

[3] Aubakirova, B., Beisenova, R., Boxall, A., Prioritization of pharmaceuticals based on risks to aquatic environments in Kazakhstan, Integrated Environmental Assessment and Management 13 (5) (2017) 832-839. https://doi.org/10.1002/ieam.1895.

[4] Bai, X., Lutz, A., Carroll, R., Keteles, K., Kenneth, D., Murphy, M., Nguyen, D., Occurrence, distribution, and seasonality of emerging contaminants in urban watersheds. Chemosphere $200 \quad$ (2018) 133-142. https://doi.org/10.1016/j.chemosphere.2018.02.106.

[5] Biel-Maeso, M., Corada-Fernández, C., LaraMartín, P. A., Monitoring the occurrence of 
pharmaceuticals in soils irrigated with reclaimed wastewater, Environmental Pollution 235 (2018) 312321. https://doi.org/10.1016/j.envpol.2017.12.085.

[6] Chen, W., Cheng, J., Lin, X. Systematic screening and identification of the chlorinated transformation products of aromatic pharmaceuticals and personal care products using high-resolution mass spectrometry, Science of the Total Environment 637-638 (2018) 253263. https://doi.org/10.1016/j.scitotenv.2018.05.011.

[7] James, J. E., Critical review of dietary caffeine and blood pressure: a relationship that should be taken more seriously, Psychosomatic Medicine 66 (1) (2004) 63-71. https://doi.org/10.1097/10.PSY.0000107884.78247.F9.

[8] Gros, M., Rodríguez-Mozaz, S., Barceló, D., Rapid analysis of multiclass antibiotic residues and some of their metabolites in hospital, urban wastewater and river water by ultra-high-performance liquid chromatography coupled to quadrupole-linear ion trap tandem mass spectrometry, Journal of Chromatography A 1292 (2013) 173-188. https://doi.org/10.1016/j.chroma.2012.12.072.

[9] United States Environmental Protection Agency. About risk assessment: learn about risk assessment. https://www.epa.gov/risk/about-riskassessment\#whatisrisk.

[10] World Health Organization (WHO); United Nations Children's Fund (UNICEF), Progress on Drinking Water, Sanitation and Hygiene: 2017 Update and SDG Baselines. https://www.unicef.org/publications/index_96611.html.

[11] Agência Nacional das Águas (ANA). Atlas Esgotos: Despoluição das bacias hidrográficas. http://atlasesgotos.ana.gov.br.

[12] BRAZIL., 23 $3^{\text {rd }}$ Diagnosis of Water and Sewage Services - 2017, Ministry of Regional Development, National Sanitation Information System. http://www.snis.gov.br/component/content/article?id=1 75.

[13] Sauvé, S., Desrosiers, M., A review of what is an emerging contaminant, Chemistry Central Journal 8 (15) (2014) 1-7. https://doi.org/10.1186/1752-153X-8-15.

[14] Bolong, N., Ismail, A.F., Salim, M.R., Matsuura, T., A review of the effects of emerging contaminants in wastewater and options for their removal, Desalination 239 (2009) 229-246. https://doi.org/10.1016/j.desal.2008.03.020.
[15] United Nations World Water Assessment Programme (WWAP). 2017. The United Nations World Water Development Report 2017. Wastewater: The Untapped Resource. Paris, UNESCO.

[16] Montagner, C. C., Vidal, C., Acayaba, R. D., Contaminantes emergentes em matrizes aquáticas do brasil: cenário atual e aspectos analíticos, ecotoxicológicos e regulatórios, Química Nova 40 (9) (2017) 1094-1110. https://doi.org/10.21577/01004042.20170091 .

[17] Guasch, H., Serra, A., Corcoll, N., Bonet, B., Leira, M., Metal ecotoxicology in fluvial biofilms: potential influence of water scarcity. In: Sabater, S., Barceló, D., (Eds) Water Scarcity in the Mediterranean. The Handbook of Environmental Chemistry, Springer Berlin Heidelberg, 2010. https://doi.org/10.1007/978-3-64203971-3.

[18] EPA. Contaminant Candidate List (CCL) and Regulatory Determination. https://www.epa.gov/ccl/contaminant-candidate-list-4ccl-4-0.

[19] Islas-Flores, H., Gómez-Oliván, L. M., Legislation Controlling the Discharge of Pharmaceuticals into the Environment. In: The Handbook of Environmental Chemistry, Ecopharmacovigilance, Springer 66 (2017) 95-117. https://doi.org/10.1007/698_2017_170.

[20] Von Der Ohe, P. C., Dulio, V., Slobodnik, J., Deckere, E., Kühne, R., Ebert, R-U., Ginebreda, A., Cooman, W., Schüürman, G., Brack, W., A new risk assessment approach for the prioritization of 500 classical and emerging organic microcontaminants as potential river basin specific pollutants under the European Water Framework Directive, Science of the Total Environment 409 (11) (2011) 2064-2077. https://doi.org/10.1016/j.scitotenv.2011.01.054.

[21] Dulio, V., Van Bavel, B., Brorström-Lundén, E., Harmsen, J., Hollender, J., Schlabach, M., Slobodnik, J., Thomas, K., Koschorreck, J., Emerging pollutants in the EU: 10 years of NORMAN in support of environmental policies and regulations, Environmental Sciences $\begin{array}{lllll}\text { Europe } & 30 & \text { (5) } & \text { (2018) }\end{array}$ https://doi.org/10.1186/s12302-018-0135-3.

[22] Wu, J., Yue, J., Hu, R., Yang, Z., Zhang, L., Use of caffeine and human pharmaceutical compounds to identify sewage contamination, International Journal of Biomedical and Biological Engineering 2 (8) (2008) 289-293. https://publications.waset.org/8464/pdf.

[23] Montagner, C. C., Umbuzeiro, G. A., Pasquini, C., Jardim, W. F., Caffeine as an indicator of estrogenic activity in source water. Environmental Science: 
Processes Impacts $16 \quad$ (8) (2014) 10-13. https://doi.org/10.1039/C4EM00058G.

[24] Gonçalves, E. S., Rodrigues, S. V., Silva-Filho, E. $\mathrm{V}$., The use of caffeine as a chemical marker of domestic wastewater contamination in surface waters: seasonal and spatial variations in Teresópolis, Brazil, Revista Ambiente \& Água 12 (2) (2016) 192-202. https://doi.org/10.4136/ambi-agua.1974.

[25] Edwards, Q. A., Kulikov, S. M., Garner-O’neale, L. D., Caffeine in surface and wastewaters in Barbados, West Indies, Springer Plus 4 (57) (2015) 1-12. https://doi.org/10.1186/s40064-015-0809-X.

[26] Gracia-Lor, E., Castiglioni, S., Bade, R., Been, F., Castrignanò, E., Covaci, A., González-Mariño, I., Hapeshi, E., Kasprzyk-Hordern, B., Kinyua, J., Lai, F. Y., Letzel, T., Lopardo, L., Meyer, M. R., O’Brien, J., Ramin, P., Rousis, N. I., Rydevik, A., Ryu, Y., Santos, M. M., Senta, I., Thomaidis, N. S., Veloutsou, S., Yang, Z., Zuccato, E., Bijlsma, L., Measuring biomarkers in wastewater as a new source of epidemiological information: Current state and future perspectives, Environment International 99 (2017) 131-150. https://doi.org/10.1016/j.envint.2016.12.016.

[27] Ferreira, A. P., Caffeine as an environmental indicator for assessing urban aquatic ecosystems, Cadernos de Saúde Pública 21 (6) (2005) 1884-1892. https://doi.org/10.1590/S0102-311X2005000600038.

[28] Senta, I., Gracia-Lor, E., Borsotti, A., Zuccato, E., Castiglioni, S., Wastewater analysis to monitor use of caffeine and nicotine and evaluation of their metabolites as biomarkers for population size assessment, Water $\begin{array}{llll}\text { Research } & 74 & \text { 23-33. }\end{array}$ https://doi.org/10.1016/j.watres.2015.02.002.

[29] González-Alonso, S., Merino, L. M., Esteban, S., Alda, M. L., Barceló, D., Durán, J. J., López-Martínez, J., Aceña, J., Pérez, S., Mastroianni, N., Silva, A., Catalá, M., Valcárcel, Y., Occurrence of pharmaceutical, recreational and psychotropic drug residues in surface water on the northern Antarctic Peninsula region, Environmental Pollution 229 (2017) 241-254. https://doi.org/10.1016/j.envpol.2017.05.060.

[30] Williams, M., Kookana, R. S., Mehta, A., Yadav, S. K., Tailor, B. L., Maheshwari, B., Emerging contaminants in a river receiving untreated wastewater from an Indian urban centre, Science of the Total $\begin{array}{llll}\text { Environment } & 647 & \text { (2019) }\end{array}$ https://doi.org/10.1016/j.scitotenv.2018.08.084.

[31] Sposito, J. C. V., Montagner, C. C., Casado, M., Navarro-Martín, L., Solórzano, J. C. J., Piña, B., Grisolia, A. B., Emerging contaminants in Brazilian rivers: Occurrence and effects on gene expression in zebrafish (Danio rerio) embryos, Chemosphere 209 (2018) 696-704. https://doi.org/10.1016/j.chemosphere.2018.06.046.

[32] Campanha, M. B., Awan, A. T., Sousa, D. N. R., Grosseli, G. M., Mozeto, A. A., Fadini, P. S., A 3-year study on occurrence of emerging contaminants in an urban stream of São Paulo State of Southeast Brazil, Environmental Science and Pollution Research 22 (10) (2015) 7936-7947. https://doi.org/10.1007/s11356-0143929-x.

[33] Montagner, C. C., Jardim, W. F. Spatial and seasonal variations of pharmaceuticals and endocrine disruptors in the Atibaia River, São Paulo State (Brazil), Journal of the Brazilian Chemical Society 22 (8) (2011) $1452-1462$ 50532011000800008

[34] Cunha, V., Burkhardt-Medicke, K., Wellner, P., Santos, M. M., Moradas-Ferreira, P., Luckenbach, T., Ferreira, M., Effects of pharmaceuticals and personal care products (PPCPs) on multixenobiotic resistance (MXR) related efflux transporter activity in zebrafish (Danio rerio) embryos, Ecotoxicology and Environmental Safety $136 \quad$ (2017) 14-23. https://doi.org/10.1016/j.ecoenv.2016.10.022.

[35] Fraz, S., Lee, A. H., Wilson, J. Y., Gemfibrozil and carbamazepine decrease steroid production in zebra fish testes (Danio rerio), Aquatic Toxicology 198 (2018) 19. https://doi.org/10.1016/j.aquatox.2018.02.006.

[36] Sehonova, P., Svobodova, Z., Dolezelova, P., Vosmerova, P., Faggio, C., Effects of waterborne antidepressants on non-target animals living in the aquatic environment: A review, Science of the Total Environment 631-632 (2018) 789-794. https://doi.org/10.1016/j.scitotenv.2018.03.076.

[37] Aguirre-Martínez, G. V., Delvalls, A. T., Laura Martín-Díaz, M. Yes, caffeine, ibuprofen, carbamazepine, novobiocin and tamoxifen have an effect on Corbicula fluminea (Müller, 1774). Ecotoxicology and Environmental Safety 120 (2015) 142-154. https://doi.org/10.1016/j.ecoenv.2015.05.036.

[38] Cruz, D., Almeida, Â., Calisto, V., Esteves, V. I., Schneider, R. J., Wrona, F. J., Soares, A. M. V. M., Figueira, E., Freitas, R., Caffeine impacts in the clam Ruditapes philippinarum: Alterations on energy reserves, metabolic activity and oxidative stress biomarkers, Chemosphere 160 (2016) 95-103. https://doi.org/10.1016/j.chemosphere.2016.06.068.

[39] Pires, A., Almeida, Â., Calisto, V., Schneider, R. J., Esteves, V. I., Wrona, F. J., Soares, A. M. V. M., 
Figueira, E., Freitas, R., Long-term exposure of polychaetes to caffeine: Biochemical alterations induced in Diopatra neapolitana and Arenicola marina, Environmental Pollution 214 (2016) 456-463. https://doi.org/10.1016/j.envpol.2016.04.031.

[40] Brandt, E. M. F., Queiroz, F. B., Afonso, R. J. C. F., Aquino, S. F., Chernicharo, C. A. L., Behaviour of pharmaceuticals and endocrine disrupting chemicals in simplified sewage treatment systems, Journal of Environmental Management 128 (2013) 718-726. https://doi.org/10.1016/j.jenvman.2013.06.003.

[41] Buttiglieri, G., Knepper, T. P. Removal of emerging contaminants in wastewater treatment: conventional activated sludge treatment. In: Barceló, D., Petrovic, M. (Eds) Emerging contaminants from industrial and municipal waste: removal technologies, The Handbook of Environmental Chemistry, Springer Berlin Heidelberg, 2008. https://doi.org/10.1007/978-3540-79210-9_1.

[42] Radjenovic, J., Matosic, M., Mijatovic, I., Petrovic, M., Barceló, D., Membrane bioreactor (MBR) as an advanced wastewater treatment technology. In: Barceló, D., Petrovic, M. (Eds) Emerging contaminants from industrial and municipal waste: removal technologies, The Handbook of Environmental Chemistry, Springer Berlin Heidelberg,

https://doi.org/10.1007/698_5_093.

[43] Kunst, B., Kosutic, K., Removal of emerging contaminants in water treatment by nanofiltration and reverse osmosis. In: Barceló, D., Petrovic, M. (Eds) Emerging contaminants from industrial and municipal waste: removal technologies, The Handbook of Environmental Chemistry, Springer Berlin Heidelberg, 2008. https://doi.org/10.1007/978-3-540-79210-9_3.

[44] Chernicharo, C. A. L. Anaerobic reactors, London: IWA, 2007.

[45] Zaiat, M., Passig, F. H., Foresti, E., Treatment of domestic sewage in horizontal-flow anaerobic immobilized biomass (HAIB) reactor, Environmental Technology $21 \quad$ (10) (2000) 1139-1145. https://doi.org/10.1080/09593330.2000.9619000.

[46] Ribeiro, R., Nardi, I. R., Fernandes, B. S., Foresti, E., Zaiat, M., BTEX removal in a horizontal-flow anaerobic immobilized biomass reactor under denitrifying conditions, Biodegradation 24 (2) (2013) 269-278. https://doi.org/10.1007/s10532-012-9585-2.

[47] Gusmão, V. R., Martins, T. H., Chinalia, F. A., Sakamoto, I. K., Thiemann, O. H., Varesche, M. B. A., BTEX and ethanol removal in horizontal-flow anaerobic immobilized biomass reactor, under denitrifying condition, Process Biochemistry 41 (6) (2006) 1391 1400. https://doi.org/10.1016/j.procbio.2006.02.001.

[48] Damianovic, M. H. R. Z., Moraes, E. M., Zaiat, M., Foresti, E., Pentachlorophenol (PCP) dechlorination in horizontal-flow anaerobic immobilized biomass (HAIB) reactors, Bioresource Technology 100 (9) (2009) 43614367. https://doi.org/10.1016/j.biortech.2009.01.076.

[49] Oliveira, L. L., Silveira Duarte, I. C., Sakamoto, I. K., Varesche, M. B. A., Influence of support material on the immobilization of biomass for the degradation of linear alkylbenzene sulfonate in anaerobic reactors, Journal of Environmental Management 90 (2) (2009) 1261-1268.

https://doi.org/10.1016/j.jenvman.2008.07.013.

[50] Chatila, S., Amparo, M. R., Carvalho, L. S., Penteado, E. D., Tomita, I. N., Santos-Neto, Á. J., Gomes, P. C. F. L., Zaiat, M., Sulfamethoxazole and ciprofloxacin removal using a horizontal-flow anaerobic immobilized biomass reactor, Environmental $\begin{array}{lllll}\text { Technology } & 37 & \text { (7) } & \text { (2016) 847-853. }\end{array}$ https://doi.org/10.1080/09593330.2015.1088072.

[51] Oliveira, G. H. D., Santos-Neto, Á. J., Zaiat, M., Removal of the veterinary antimicrobial sulfamethazine in a horizontal-flow anaerobic immobilized biomass (HAIB) reactor subjected to step changes in the applied organic loading rate, Journal of Environmental Management $204 \quad$ (1) (2017) 674-683 https://doi.org/10.1016/j.jenvman.2017.09.048.

[52] Oliveira, C. A., Penteado, E. D., Tomita, I. N., Santos-Neto, Á. J., Zaiat, M., Silva, B. F., Gomes, P. C. F. L. Removal kinetics of sulfamethazine and its transformation products formed during treatment using a horizontal flow-anaerobic immobilized biomass bioreactor, Journal of Hazardous Materials 365 (2019) 34-43. https://doi.org/10.1016/j.jhazmat.2018.10.077.

[53] Martins, G. S., Luchiari, N. C., Lamarca, R. S., Silva, B. F., Gomes, P. C. F. L., Removal of sulfamethoxazole and trimethoprim using horizontalflow anaerobic immobilized bioreactor, Scientia $\begin{array}{lllll}\text { Chromatographica } & 9 & \text { (4) 2017) 253-264. }\end{array}$ http://www.iicweb.org/scientiachromatographica.com/f iles/v9n4a04.pdf.

[54] Rodríguez, A., Rosal, R., Perdigón-Melón, J. A., Mezcua, M., Aguera, A., Hernando, M. D., Letón, P., Fernández-Alba, A. R., García-Calvo, E., Ozone-based technologies in water and wastewater treatment. In: Barceló, D., Petrovic, M. (Eds) Emerging contaminants from industrial and municipal waste: removal technologies, The Handbook of Environmental Chemistry, Springer Berlin Heidelberg, 2008. https://doi.org/10.1007/698_5_103. 
[55] Malato, S., Removal of emerging contaminants in waste-water treatment: removal by photo-catalytic processes. In: Barceló, D., Petrovic, M. (Eds) Emerging contaminants from industrial and municipal waste: removal technologies, The Handbook of Environmental Chemistry, Springer Berlin Heidelberg, 2008. https://doi.org/10.1007/978-3-540-79210-9_5.

[56] Jovancic, P., Radetic, M., Advanced sorbent materials for treatment of wastewaters. In: Barceló, D., Petrovic, M., (Eds) Emerging contaminants from industrial and municipal waste: removal technologies, The Handbook of Environmental Chemistry, Springer Berlin Heidelberg, 2008. https://doi.org/10.1007/698_5_097.

[57] Barceló, D., Petrovic, M., Conclusions and future research needs. In: Barceló, D., Petrovic, M. (Eds) Emerging contaminants from industrial and municipal waste: removal technologies, The Handbook of Environmental Chemistry, Springer Berlin, Heidelberg, 2008. https://doi.org/10.1007/698_5_109.

[58] EPA. Method 1694: Pharmaceuticals and Personal Care Products in Water, Soil, Sediment, and Biosolids by HPLC/MS/MS. December, 2007. https://www.epa.gov/sites/production/files/201510/documents/method_1694_2007.pdf.

[59] EPA. Method 1698: Steroids and Hormones in Water, Soil, Sediment, and Biosolids by HRGC/HRMS. December, 2007. https://www.epa.gov/sites/production/files/201510/documents/method_1698_2007.pdf.

[60] Leite, G. S., Afonso, R. J. C. F., Aquino, S. F., Caracterização de contaminantes presentes em sistemas de tratamento de esgotos, por cromatografia líquida acoplada à espectrometria de massas tandem em alta resolução, Química Nova 33 (3) (2010) 734-738. https://doi.org/10.1590/S0100-40422010000300044.

[61] Silva, C. G. A., Collins, C. H., Aplicação de cromatografia líquida de alta eficiência para o estudo de poluentes orgânicos emergentes, Química Nova 34 (4) (2011) 665-676. https://doi.org/10.1590/S010040422011000400020 .

[62] Silva, B. F., Jelic, A., López-Serna, R., Mozeto, A. A., Petrovic, M., Barceló, D., Occurrence and distribution of pharmaceuticals in surface water, suspended solids and sediments of the Ebro river basin, Spain, Chemosphere 85 (8) (2011) 1331-1339. https://doi.org/10.1016/j.chemosphere.2011.07.051.

[63] Stewart, M., Olsen, G., Hickey, C. W., Ferreira, B., Jelić, A., Petrović, M., Barceló, D., A survey of emerging contaminants in the estuarine receiving environment around Auckland, New Zealand, Science of the Total Environment 468-469 (2014) 202-210. https://doi.org/10.1016/j.scitotenv.2013.08.039.

[64] Jardim, I. C. S. F. Extração em fase sólida: fundamentos teóricos e novas estratégias para preparação de fases sólidas, Scientia Chromatographica 2 (1) (2010) 13-25. http://www.iicweb.org/scientiachromatographica.com/f iles/v2n1a2.pdf.

[65] Dimpe, K. M., Nomngongo, P. N., Current sample preparation methodologies for analysis of emerging pollutants in different environmental matrices, Trends in

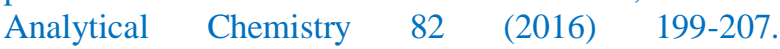
https://doi.org/10.1016/j.trac.2016.05.023.

[66] Gilart, N., Borrull, F., Fontanals, N., Marcé, R. M., Selective materials for solid-phase extraction in environmental analysis, Trends in Environmental Analytical Chemistry 1 (2014) e8-e18. https://doi.org/10.1016/j.teac.2013.11.002.

[67] Evans, S. E., Davies, P., Lubben, A., KasprzykHordern, B., Determination of chiral pharmaceuticals and illicit drugs in wastewater and sludge using microwave assisted extraction, solid-phase extraction and chiral liquid chromatography coupled with tandem mass spectrometry, Analytica Chimica Acta 882 (2015) 112-126. https://doi.org/10.1016/j.aca.2015.03.039.

[68] Vazquez-Roig, P., Andreu, V., Blasco, C., Picó, Y., SPE and LC-MS/MS determination of 14 illicit drugs in surface waters from the Natural Park of L'Albufera (València, Spain), Analytical and Bioanalytical

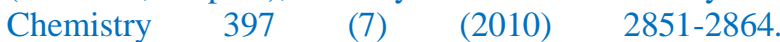
https://doi.org/10.1007/s00216-010-3720-x.

[69] Buszewski, B., Szultka, M., Past, present, and future of solid phase extraction: a review, Critical Reviews in Analytical Chemistry 42 (3) (2012) 198-213. https://doi.org/10.1080/07373937.2011.645413.

[70] Van Nuijs, A. L. N., Tarcomnicu, I., Simons, W., Bervoets, L., Blust, R., Jorens, P. G., Neels, H., Covaci, A., Optimization and validation of a hydrophilic interaction liquid chromatography-tandem mass spectrometry method for the determination of 13 topprescribed pharmaceuticals in influent wastewater, Analytical and Bioanalytical Chemistry 398 (5) (2010) 2211-2222. https://doi.org/10.1007/s00216-010-41011.

[71] Gros, M., Petrovic, M., Barceló, D. Development of a multi-residue analytical methodology based on liquid chromatography-tandem mass spectrometry (LC-MS/MS) for screening and trace level determination of pharmaceuticals in surface and 
wastewaters, Talanta $70 \quad$ (4) (2006) 678-690.

https://doi.org/10.1016/j.talanta.2006.05.024.

[72] Babic, S., Pavlovic, D. M., Asperger, D., Perisa, M., Zrncic, M., Horvat, A. J. M., Kastelan-Macan, M., Determination of multi-class pharmaceuticals in wastewater by liquid chromatography-tandem mass spectrometry (LC-MS-MS), Analytical and Bioanalytical Chemistry 398 (3) (2010) 1185-1194. https://doi.org/10.1007/s00216-010-4004-1.

[73] Pedrouzo, M., Borrull, F., Marcé, R. M., Pocurull, E., Ultra-high-performance liquid chromatographytandem mass spectrometry for determining the presence of eleven personal care products in surface and wastewaters, Journal of Chromatography A 1216 (42) (2009) 6994-7000.

https://doi.org/10.1016/j.chroma.2009.08.039.

[74] Andrade-Eiroa, A., Canle, M., Leroy-Cancellieri, V., Cerda, V., Solid-phase extraction of organic compounds: a critical review (part I), Trends in Analytical Chemistry $80 \quad$ (2016) 641-654. https://doi.org/10.1016/j.trac.2015.08.015.

[75] Gomes, P. C. F. L., Tomita, I. N., Santos-Neto, Á. J., Zaiat, M., Rapid determination of 12 antibiotics and caffeine in sewage and bioreactor effluent by online column-switching liquid chromatography/tandem mass spectrometry, Analytical and Bioanalytical Chemistry $407 \quad$ (29) (2015) 8787-8801. https://doi.org/10.1007/s00216-015-9038-y.

[76] Rodriguez-Mozaz, S., Alda, M. J. L., Barceló, D., Advantages and limitations of on-line solid phase extraction coupled to liquid chromatography-mass spectrometry technologies versus biosensors for monitoring of emerging contaminants in water, Journal of Chromatography A 1152 (1-2) (2007) 97-115. https://doi.org/10.1016/j.chroma.2007.01.046. 